\title{
Characterisation of Shoe Soling Material Prepared by using Rubber and Leather Solid Waste
}

\author{
S. Ponsubbiah, Sanjeev Gupta
}

\begin{abstract}
The ultimate aim of this research is to develop footwear soling materials from solid waste generated from leather industry. The Chrome shaving from the leather sector is used as a solid waste in this study. Styrene butadiene, Nitryl, Ethylene propylene monomer (EPDM) and Isoprene elastomers were used for this research. The rubber and chrome shavings mixes were prepared by using industrial two roll mill. Various propositions of rubbers, chrome shavings and nano fillers were characterised in this research. The developed soling materials were tested for physical testing like hardness, abrasion resistance, tensile strength, density and elongation at break and compared with compared with commercially available soling material. In this research four different experiments has been conducted among the four experiments the soling material prepared using a isoprene rubber-70 Phr and EPDM rubber $30 \mathrm{Phr}$ with chrome shavings -50 Phr and KLN(Silica based) nano fillers- $7 \mathrm{Phr}$ meets the required parameters of commercial soling material. Hence, it is concluded that chrome shaving wastes from tannery in soling material preparation is one of the best remedy for the environmental issues.

; Key words
\end{abstract}

- Phr-Parts per hundred parts of rubber

- EPDM-Ethylene propylene Diene Monomer

- NBR-Nitryl Rubber

- SBR-Styrene butadiene Rubber

- SEM-Scanning Electron Microscope

\section{INTRODUCTION}

Leather industry plays a vital role in Indian economy in terms of export earnings and employment. The solid and liquid waste generated in the various unit operations of leather processing is unavoidable. For sustainable development, leather industries need to reduce those wastes to meet all the vindicate standards. Certain solid wastes are generated because of the chemicals involved in leather processing. Raw trimmings, desalting salts, fleshing, hairs, Chrome shaving and snuffing /buffing dust \& leather trimmings are the wastes generated from the various unit operations in leather processing. In India, according to the survey conducted by the Central leather research institute around 2.2 crore of buffalos, 2.4 crore of cattle's, 3.7 crore of sheeps and 10.6 crore of goats hides and skins are available live stock for leather processing in the various tanneries in India. Around 0.2 million tonnes of solid waste generated per year (CLRI, 2015) and Chrome shaving waste are consider to be a hazardous waste since chrome (VI) present in the shavings.

Revised Manuscript Received on December 30, 2019.

* Correspondence Author

S.Ponsubbiah, Lecturer, Institute of Leather Technology, Tharamani, Chennai (Tamil Nadu) India. 113. ponsubbiah@gmail.com

Dr.Sanjeev Gupta, Chief Scientist, CSIR- CLRI, Adyar,Chennai(Tamil Nadu) India.-20. sgupta1281@gmail.com

(C) The Authors. Published by Blue Eyes Intelligence Engineering and Sciences Publication (BEIESP). This is an open access article under the CC BY-NC-ND license (http://creativecommons.org/licenses/by-nc-nd/4.0/)
The safe disposal of chrome shavings to be addressed to avoid environmental issues. Currently, chrome solid wastes are utilized as-

$>$ Composites made from chrome shavings and natural fibers using rubber solution (US Patent)(Parrini et. al. 1979)

$>$ Preparation of leather like materials using synthetic and natural blend polymer (US Patent)(Parrini et.al. 1979)

$>$ Value added composite from leather and no-leather fibers (US Patent) (Parrini et. al. 1979)

$>$ Sustainable Landfill (Indian Patent No.125DEL 2006)

$>$ Production of parchment like materials (Indian Patent No.300DEL 1999)

However, the above applications have not been commercialised on industry level. Other utilities do not find much use due to cost constrains and feasibility. The below figure 1 elaborated the research methodology of this research.

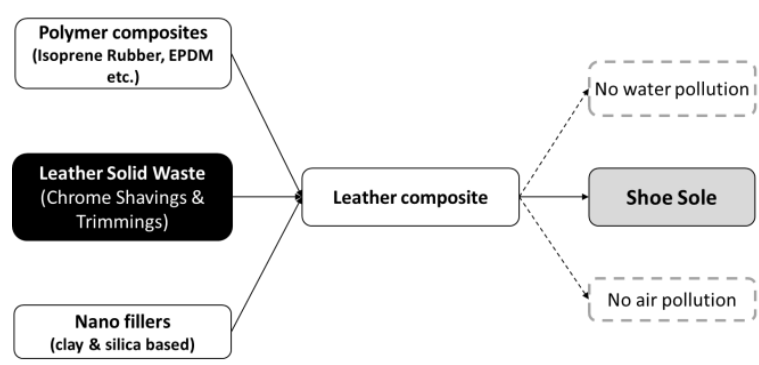

Figure 1. Methodology of this research

\section{MATERIALS}

In this trial to prepare of soling materials EPDM rubber, Nitryl rubber, Styrene butadiene rubber and Isoprene rubber were used. The activator used in this study is Zinc oxide and Stearic Acid \& the accelerator used in this study is MBTS, CBS \& TMT and sulphur and other chemicals used is laboratory grade. KLN, SI and BNT nano fillers were sourced from Sigma Aldrich Ltd. Chrome solid waste (shavings) were obtained from the local tannery in Chennai. Chromium and Nitrogen is the major constituent of chrome shaving. Normally chrome shavings are acidic in nature; this causes interruption during the vulcanisation process. In order to conquer the acidic nature, the shavings were treated with $1 \%$ solution of urea, aqueous ammonia and alkaline salts. Then chrome shavings were tested in CLRI laboratory for various characterisations. The tested chrome shaving fibres were dried in sun light for 24 hours and after, the particles size of the chrome shavings were reduced by strap cutting machine. 
Characterisation of Shoe Soling Material Prepared by using Rubber and Leather Solid Waste

Table 1: Material used in this research

\begin{tabular}{|l|l|l|}
\hline $\begin{array}{c}\text { Name of } \\
\text { Compounding } \\
\text { material }\end{array}$ & $\begin{array}{c}\text { Role of } \\
\text { Compounding } \\
\text { material }\end{array}$ & \multicolumn{1}{|c|}{ Sourcing } \\
\hline Isoprene rubbers & Elastomer & $\begin{array}{l}\text { Riddhi Polymers, } \\
\text { Chennai }\end{array}$ \\
\hline $\begin{array}{l}\text { Styrene } \\
\text { Butadiene Rubber }\end{array}$ & Elastomer & $\begin{array}{l}\text { Riddhi Polymers, } \\
\text { Chennai }\end{array}$ \\
\hline Nitryl Rubber & Elastomer & $\begin{array}{l}\text { Riddhi Polymers, } \\
\text { Chennai }\end{array}$ \\
\hline EPDM & Elastomer & $\begin{array}{l}\text { Riddhi Polymers, } \\
\text { Chennai }\end{array}$ \\
\hline Chrome shaving & Solid waste/filler & $\begin{array}{l}\text { Viralli } \\
\text { Enterprises,Chennai- } \\
44\end{array}$ \\
\hline Zinc oxide & Activator & Nocil Ltd,Mumbai \\
\hline Stearic acid & Activator & Nocil Ltd,Mumbai \\
\hline CBS & Accelerator & Nocil Ltd,Mumbai \\
\hline MBTS & Accelerator & Nocil Ltd,Mumbai \\
\hline TMT & Accelerator & Nocil Ltd,Mumbai \\
\hline SULPHUR & Fulcanising & Nocil Ltd,Mumbai \\
\hline BNT,KLN \& SI & Nano fillers & Nocil Ltd,Mumbai \\
\hline
\end{tabular}

\subsection{Machinery used}

The following equipment /machineries were used to conduct the experiments:

- Two roll mill (with roller dimension $\mathrm{D}=220 \mathrm{~mm}$ and $\mathrm{L}=$ $450 \mathrm{~mm})$

- Compression moulding machine

- Strap cutting machine(for chrome shaving fibre length reduction)

\section{PREPARATION OF FOOTWEAR COMPONENTS}

To prepare rubber compounding mixes two roll mill were used. In two roll mill the roll speed were maintained at $\mathbf{V}_{0}=$ $15 \mathrm{rpm}$ and temperature was maintained at 320-340K. The elastomers and other ingredient were passed into the two roll mill with a thickness of $6-8 \mathrm{~mm}$ and then stored at 270 $310 \mathrm{~K}$. The commercially available soling materials were as control in this experiment. In order to develop footwear components four different experiments has been conducted using different elastomers and leather solid waste.

\subsection{Experiment I}

In this experiment seven different compositions of rubber mixes were prepared by using Isoprene, Styrene butadiene, Nitryl \& EPDM rubbers along with pre treated chrome shaving and caco3 filler. The various composition of this experiments are shown in the below Table 2 .
Table 2: Trial with Isoprene, Nitryl, Styrene butadiene and EPDM Rubbers

\begin{tabular}{|c|c|c|c|c|c|c|c|}
\hline $\begin{array}{l}\text { Trial } \\
\text { 1(A1) }\end{array}$ & $\begin{array}{l}\text { Trial } \\
\text { 2(A2 } \\
\text { ) }\end{array}$ & $\begin{array}{r}\text { Trial } \\
\text { 3(A3) }\end{array}$ & $\begin{array}{l}\text { Trial } \\
\text { 4(A4) }\end{array}$ & $\begin{array}{c}\text { Trial } \\
\text { 5(A5) }\end{array}$ & $\begin{array}{l}\text { Trial } \\
\text { 6(A6) }\end{array}$ & $\begin{array}{l}\text { Trial } \\
7(A 7)\end{array}$ & $\begin{array}{l}Q \\
\text { ty } \\
(P \\
\text { hr } \\
\text { ) }\end{array}$ \\
\hline $\begin{array}{l}\text { Isopre } \\
\text { ne }\end{array}$ & SBR & NBR & EPDM & $\begin{array}{c}\text { Isoprene } \\
+ \\
\text { EPDM }\end{array}$ & $\begin{array}{l}\text { SBR+ } \\
\text { EPDM }\end{array}$ & $\begin{array}{l}\text { NBR+ } \\
\text { EPDM }\end{array}$ & $\begin{array}{c}10 \\
0\end{array}$ \\
\hline $\begin{array}{l}\text { Chrom } \\
\text { e } \\
\text { shavin } \\
\text { g }\end{array}$ & $\begin{array}{c}\text { Chro } \\
\text { me } \\
\text { shavi } \\
\text { ng } \\
\end{array}$ & $\begin{array}{l}\text { Chrom } \\
\text { e } \\
\text { shavin } \\
\text { g }\end{array}$ & $\begin{array}{l}\text { Chrom } \\
\text { e } \\
\text { shavin } \\
\text { g }\end{array}$ & $\begin{array}{l}\text { Chrome } \\
\text { shaving }\end{array}$ & $\begin{array}{l}\text { Chrom } \\
\text { e } \\
\text { shavin } \\
\text { g }\end{array}$ & $\begin{array}{l}\text { Chrom } \\
\text { e } \\
\text { shavin } \\
\text { g }\end{array}$ & 50 \\
\hline $\begin{array}{c}\text { Zinc } \\
\text { oxide }\end{array}$ & $\begin{array}{c}\text { Zinc } \\
\text { oxid } \\
\text { e }\end{array}$ & $\begin{array}{l}\text { Zinc } \\
\text { oxide }\end{array}$ & $\begin{array}{l}\text { Zinc } \\
\text { oxide }\end{array}$ & $\begin{array}{l}\text { Zinc } \\
\text { oxide }\end{array}$ & $\begin{array}{l}\text { Zinc } \\
\text { oxide }\end{array}$ & $\begin{array}{l}\text { Zinc } \\
\text { oxide }\end{array}$ & 10 \\
\hline $\begin{array}{c}\text { Stearic } \\
\text { acid }\end{array}$ & $\begin{array}{l}\text { Stear } \\
\text { ic } \\
\text { acid }\end{array}$ & $\begin{array}{c}\text { Stearic } \\
\text { acid }\end{array}$ & $\begin{array}{c}\text { Stearic } \\
\text { acid }\end{array}$ & $\begin{array}{c}\text { Stearic } \\
\text { acid }\end{array}$ & $\begin{array}{c}\text { Stearic } \\
\text { acid }\end{array}$ & $\begin{array}{c}\text { Stearic } \\
\text { acid }\end{array}$ & 4 \\
\hline CBS & CBS & CBS & CBS & CBS & CBS & CBS & 1 \\
\hline MBTS & $\begin{array}{c}\text { MBT } \\
\text { S }\end{array}$ & MBTS & MBTS & MBTS & MBTS & MBTS & 1 \\
\hline TMT & TMT & TMT & TMT & TMT & TMT & TMT & $\begin{array}{l}0 . \\
5\end{array}$ \\
\hline $\begin{array}{c}\text { Sulphu } \\
\text { r }\end{array}$ & $\begin{array}{l}\text { Sulp } \\
\text { hur }\end{array}$ & $\begin{array}{c}\text { Sulphu } \\
\text { r }\end{array}$ & $\begin{array}{c}\text { Sulphu } \\
\text { r }\end{array}$ & Sulphur & $\begin{array}{c}\text { Sulphu } \\
\text { r }\end{array}$ & $\begin{array}{c}\text { Sulphu } \\
\text { r }\end{array}$ & 5 \\
\hline $\mathrm{CaCO}_{3}$ & $\begin{array}{c}\mathrm{CaC} \\
\mathrm{O}_{3}\end{array}$ & $\mathrm{CaCO}_{3}$ & $\mathrm{CaCO}_{3}$ & $\mathrm{CaCO}_{3}$ & $\mathrm{CaCO}_{3}$ & $\mathrm{CaCO}_{3}$ & 50 \\
\hline
\end{tabular}

\subsection{Experiment II}

In this experiment four different compositions of rubber mixes were prepared by using different proposition of Isoprene, EPDM rubbers along with pre treated chrome shaving and caco3 filler. The various composition of this experiments are shown in the below Table 3.

Table 3: Trial with different proposition of Isoprene and EPDM Rubbers

\begin{tabular}{|c|c|c|c|c|c|c|c|}
\hline $\begin{array}{l}\text { Trial } \\
\text { 1(B1) }\end{array}$ & $\begin{array}{l}\text { Qty } \\
\text { (Ph } \\
\text { r) }\end{array}$ & $\begin{array}{l}\text { Trial } \\
\text { 2(B2) }\end{array}$ & $\begin{array}{l}\text { Qty( } \\
\text { Phr) }\end{array}$ & $\begin{array}{l}\text { Trial } \\
\text { 3(B3) }\end{array}$ & $\begin{array}{l}\mathbf{Q t} \\
\text { y( } \\
\text { Ph } \\
\text { r) }\end{array}$ & $\begin{array}{l}\text { Trial } \\
\text { 4(B4) }\end{array}$ & $\begin{array}{l}\text { Qty( } \\
\text { Phr) }\end{array}$ \\
\hline $\begin{array}{c}\text { Isoprene } \\
+ \\
\text { EPDM }\end{array}$ & $\begin{array}{c}60 / 4 \\
0\end{array}$ & $\begin{array}{c}\text { Isopren } \\
\mathrm{e}^{+} \\
\text {EPDM }\end{array}$ & $\begin{array}{c}70 / 3 \\
0\end{array}$ & $\begin{array}{c}\text { Isoprene } \\
+ \\
\text { EPDM }\end{array}$ & $\begin{array}{c}80 \\
/ 2 \\
0\end{array}$ & $\begin{array}{l}\text { NBR+ } \\
\text { EPDM }\end{array}$ & $\begin{array}{c}90 / 1 \\
0\end{array}$ \\
\hline $\begin{array}{l}\text { Chrome } \\
\text { shaving }\end{array}$ & 50 & $\begin{array}{c}\text { Chrom } \\
\text { e } \\
\text { shaving }\end{array}$ & 50 & $\begin{array}{l}\text { Chrome } \\
\text { shaving }\end{array}$ & 50 & $\begin{array}{l}\text { Chrome } \\
\text { shaving }\end{array}$ & 50 \\
\hline $\begin{array}{c}\text { Zinc } \\
\text { oxide }\end{array}$ & 10 & $\begin{array}{c}\text { Zinc } \\
\text { oxide }\end{array}$ & 10 & $\begin{array}{c}\text { Zinc } \\
\text { oxide }\end{array}$ & 10 & $\begin{array}{c}\text { Zinc } \\
\text { oxide }\end{array}$ & 10 \\
\hline $\begin{array}{c}\text { Stearic } \\
\text { acid }\end{array}$ & 4 & $\begin{array}{c}\text { Stearic } \\
\text { acid }\end{array}$ & 4 & $\begin{array}{c}\text { Stearic } \\
\text { acid }\end{array}$ & 4 & $\begin{array}{c}\text { Stearic } \\
\text { acid }\end{array}$ & 4 \\
\hline CBS & 1 & CBS & 1 & CBS & 1 & CBS & 1 \\
\hline MBTS & 1 & MBTS & 1 & MBTS & 1 & MBTS & 1 \\
\hline TMT & 0.5 & TMT & 0.5 & TMT & $\begin{array}{l}0 . \\
5\end{array}$ & TMT & 0.5 \\
\hline Sulphur & 5 & $\begin{array}{l}\text { Sulphu } \\
\text { r }\end{array}$ & 5 & Sulphur & 5 & Sulphur & 5 \\
\hline $\mathrm{CaCO}_{3}$ & 50 & $\mathrm{CaCO}_{3}$ & 50 & $\mathrm{CaCO}_{3}$ & 50 & $\mathrm{CaCO}_{3}$ & 50 \\
\hline
\end{tabular}

\subsection{Experiment III}

In this experiment three different compositions of rubber mixes were prepared by using Isoprene-70 Phr, EPDM -30 Phr and pre treated chrome shaving-50 Phr along with three different types of nanoparticle. The various composition of this experiments are shown in the below Table 4. 
Table 4: Trial with Isoprene and EPDM Rubber with different nanoparticle

\begin{tabular}{|c|c|c|c|}
\hline Trial 1(C1) & Trial 2(C2) & Trial 3(C3) & Qty(Phr) \\
\hline $\begin{array}{c}\text { Isoprene+ } \\
\text { EPDM }\end{array}$ & $\begin{array}{c}\text { Isoprene+ } \\
\text { EPDM }\end{array}$ & $\begin{array}{c}\text { Isoprene+ } \\
\text { EPDM }\end{array}$ & $70 / 30$ \\
\hline Zincome shaving & $\begin{array}{c}\text { Chrome } \\
\text { shaving }\end{array}$ & $\begin{array}{c}\text { Chrome } \\
\text { shaving }\end{array}$ & 50 \\
\hline Stearic acid & Zinc oxide & Zinc oxide & 10 \\
\hline CBS & CBS & CBS & 1 \\
\hline MBTS & MBTS & MBTS & 1 \\
\hline TMT & TMT & TMT & 0.5 \\
\hline Sulphur & Sulphur & Sulphur & 5 \\
\hline BNT & KLN & SI & 5 \\
\hline
\end{tabular}

\subsection{Experiment IV}

In this experiment six different compositions of rubber mixes were prepared by using Isoprene-70 Phr, EPDM -30 Phr and pre treated chrome shaving-50 Phr along with various quantity of KLN nanoparticle. The various composition of this experiments are shown in the below Table 5.

Table 5: Trial with Isoprene and EPDM Rubber with different quantity of KLN nanoparticle

\begin{tabular}{|c|c|c|c|c|c|c|}
\hline Composition & Trial 1(D1) & $\begin{array}{c}\text { Trial } \\
\text { 2(D2) }\end{array}$ & $\begin{array}{c}\text { Trial } \\
\text { 3(D3) }\end{array}$ & $\begin{array}{c}\text { Trial } \\
\text { 4(D4) }\end{array}$ & $\begin{array}{c}\text { Trial } \\
\text { 5(D5) }\end{array}$ & $\begin{array}{c}\text { Trial } \\
\text { 6(D6) }\end{array}$ \\
\hline $\begin{array}{c}\text { Isoprene+ } \\
\text { EPDM }\end{array}$ & $70 / 30$ & $70 / 30$ & $70 / 30$ & $70 / 30$ & $70 / 30$ & $70 / 30$ \\
\hline $\begin{array}{c}\text { Chrome } \\
\text { shaving }\end{array}$ & 50 & 50 & 50 & 50 & 50 & 50 \\
\hline $\begin{array}{c}\text { Zinc } \\
\text { oxide }\end{array}$ & 10 & 10 & 10 & 10 & 10 & 10 \\
\hline $\begin{array}{c}\text { Stearic } \\
\text { acid }\end{array}$ & 4 & 4 & 4 & 4 & 4 & 4 \\
\hline CBS & 1 & 1 & 1 & 1 & 1 & 1 \\
\hline MBTS & 1 & 1 & 1 & 1 & 1 & 1 \\
\hline TMT & 0.5 & 0.5 & 0.5 & 0.5 & 0.5 & 0.5 \\
\hline Sulphur & 5 & 5 & 5 & 5 & 5 & 5 \\
\hline KLN & 1 & 3 & 5 & 7 & 9 & 11 \\
\hline
\end{tabular}

Figure 2: SEM images of the fractured surfaces of samplesA7, B2, C2 and D4.
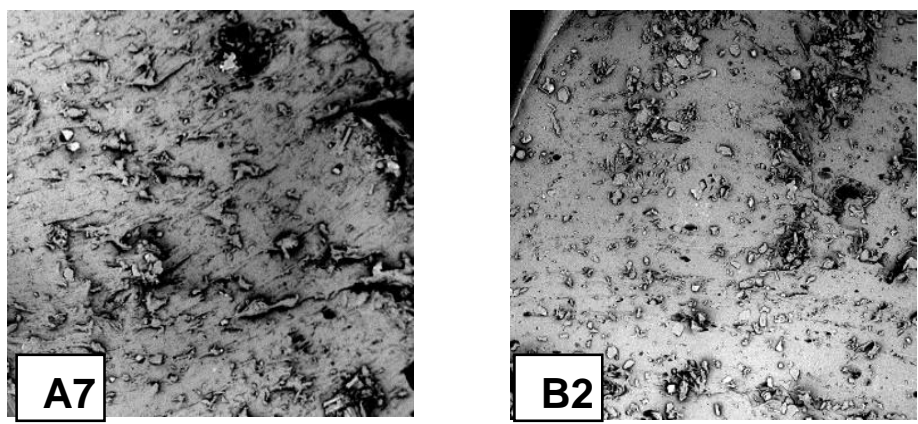

\subsection{Curing}

The various trails were carried out in this research and the following parameters were maintained in the curing process

Table 6: Curing Parameters

\begin{tabular}{|c|l|l|}
\hline S.No & Parameters & Values \\
\hline 1. & Temperature & $\begin{array}{l}140^{0} \mathrm{C}- \\
160^{\circ} \mathrm{C}\end{array}$ \\
\hline 2. & Pressure & $\begin{array}{l}250 \\
\mathrm{Kg} / \mathrm{cm}^{2}\end{array}$ \\
\hline 3. & $\begin{array}{l}\text { Time of } \\
\text { curing }\end{array}$ & $\begin{array}{l}5-12 \\
\text { minutes }\end{array}$ \\
\hline
\end{tabular}

Appropriate male and female moulds were used in this study and pre-weighed rubber mixes were placed inside the mould.

\subsection{Characterisation}

The surface and cross-sectional morphology of shoe soling materials were studied by Scanning Electron Microscopy SEM (model: Phenom Pro \& make: Phenom world,). Physical properties of the developed shoe soling materials were studied using

1. Universal Test Machine (model: 3369/J7257INSTRON)

2. Bata Flexing Resistance (Model: STM 612SATRA)

3. Leather Sole Abrasion Tester (Model: STM 140SATRA)

\section{RESULTS AND DISCUSSIONS OF THIS STUDY}

4.1 SEM-Scanning Electron Microscopic images of soling materials

The Scanning Electron Microscopy images of the tensile tested specimens of all the above four experiments were shown in the below figures
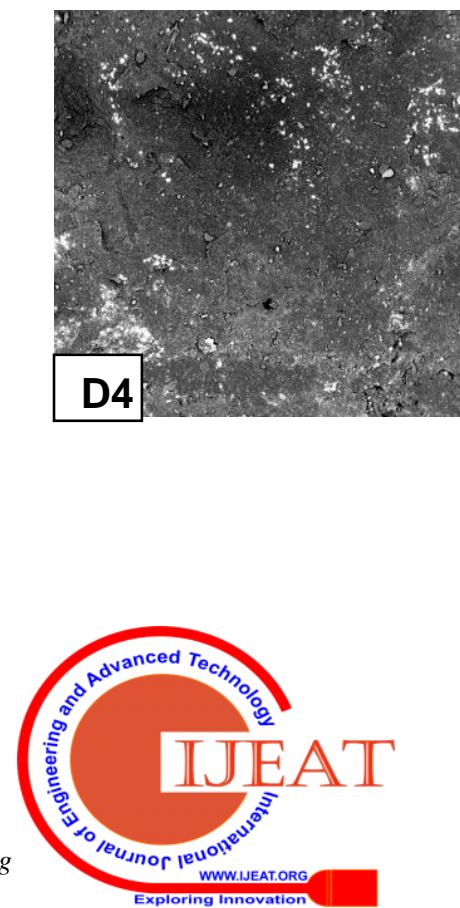


\section{Characterisation of Shoe Soling Material Prepared by using Rubber and Leather Solid Waste}

The Scanning Electron Microscopy images of the trail I, II, III and Trail IV are shown in Fig. 2. The Scanning Electron Microscopy images of shoe soling samples A7, B2, C2 and D4 show aggregation of fibre due to blending of Isoprene and EPDM with chrome shavings. The SEM image reveals that in all four samples chrome shavings are intermingled with polymers and also can be seen that in all the six samples chrome shavings are closely knitted.

\subsection{IR Spectroscopy}

The IR images of the samples are shown in the below figure 3. The final sample demonstrates the absorption at $1045 \mathrm{~cm}^{-}$ 1, $1150 \mathrm{~cm}^{-1}$ and $1170 \mathrm{~cm}^{-1}$ whichreveals that the more functional groups present in the sample. The IR spectrum shows multiple bands between $3450 \mathrm{~cm}^{-1}$ to $2630 \mathrm{~cm}^{-1}$ and this indicates the presence of leather fibres in the composite.

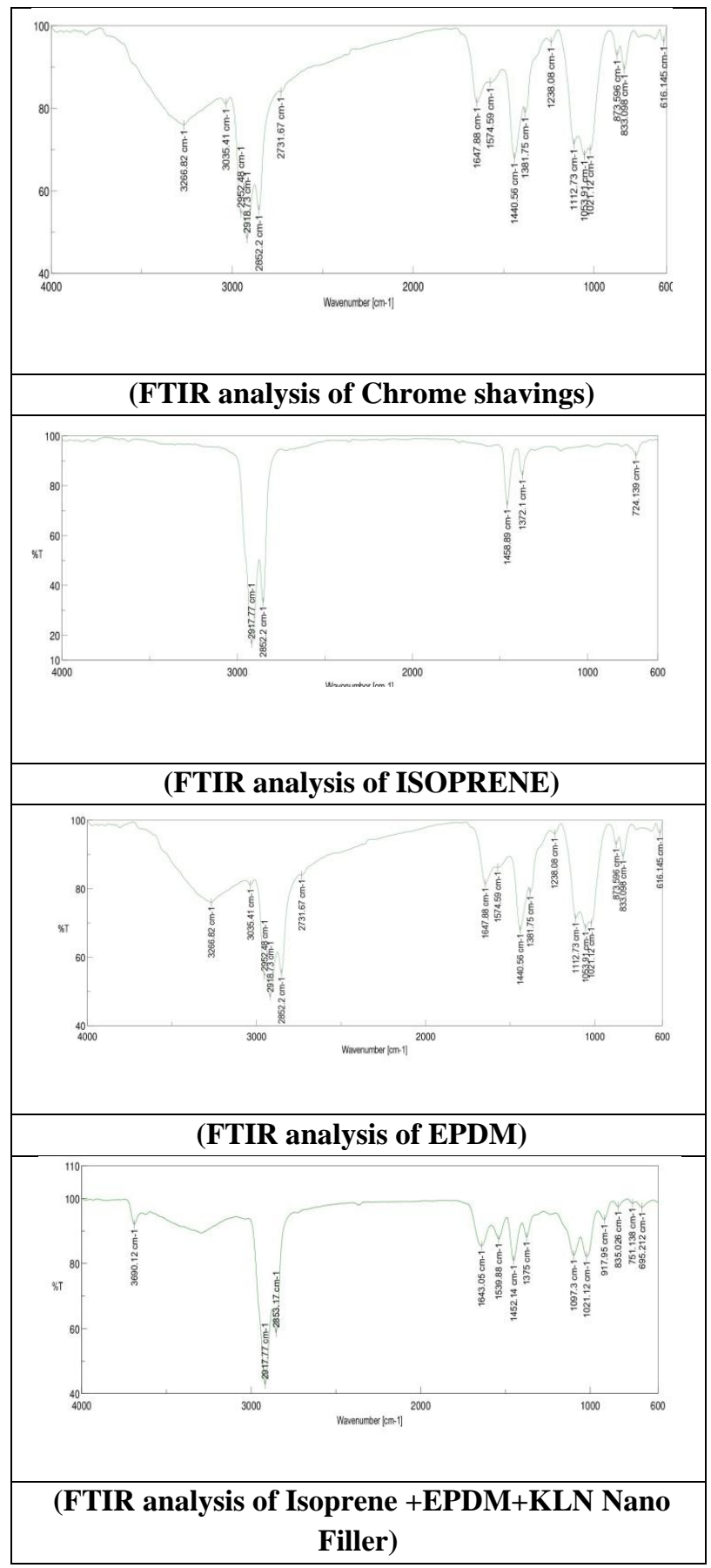

Figure 3: FTIR analysis of Isoprene and EPDM rubbers

\subsection{Physical testing and their impacts}

The prepared soling materials were subjected to the following physical testing
1. Abrasion resistance,
2. Tensile strength,
3. Percentage of elongation at break,
4. Hardness,
5. Density
6. Flexing endurance.

The test results of the soling materials were compared with standard value of the control. The commercial rubber soling material is used as a control in this study and it was purchased from sole unit in Ranipet. The physical properties of the control soling material are listed in the table 7 :

Table 7: Values of physical properties of the control soling material

\begin{tabular}{cll}
\hline S.No & $\begin{array}{c}\text { Physical } \\
\text { properties }\end{array}$ & \multicolumn{1}{c}{$\begin{array}{c}\text { Test } \\
\text { Values }\end{array}$} \\
\hline $\mathbf{1}$ & $\begin{array}{l}\text { Percentage of } \\
\text { Elongation }\end{array}$ & $220 \%$ \\
\hline $\mathbf{2}$ & Density & 1.25 \\
& & gm/cc \\
\hline $\mathbf{3}$ & Tensile strength & $6.0 \mathrm{MPa}$ \\
\hline $\mathbf{4}$ & Abrasion Resistance & $162 \mathrm{~mm}{ }^{3}$ \\
& & \\
\hline $\mathbf{5}$ & Thickness & $8 \mathrm{~mm}$ \\
\hline $\mathbf{6}$ & Hardness & $65($ Shore \\
& & A) \\
& & \\
\hline $\mathbf{7}$ & Flexing endurance & 52000 \\
& & flexes \\
\hline
\end{tabular}

The physical properties of the soling material prepared by Nitryl rubber, Styrene butadiene rubber, isoprene rubber and EPDM rubber with chrome waste are tabulated in the table 8. The soling material prepared by using different proposition of EPDM rubber and isoprene rubber with chrome waste are tabulated in the table 9. The soling material prepared by mixture of isoprene and EPDM rubber along with chrome waste and nano fillers are tabulated in the table 10. The soling materials prepared by isoprene and EPDM rubber with chrome shaving waste and different quantity of nano fillers are presented in table 11.

Table 8: Physical properties of soling materials prepared by different elatomers and chrome waste.

\begin{tabular}{|c|c|c|c|c|c|c|}
\hline 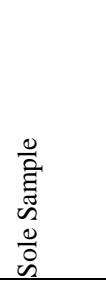 & 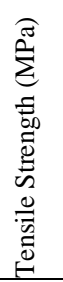 & 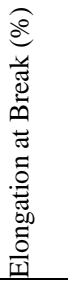 & 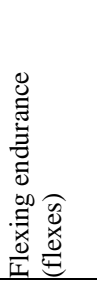 & 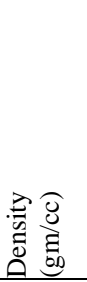 & 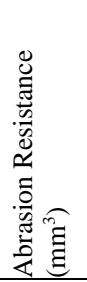 & 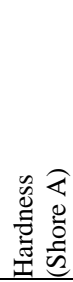 \\
\hline Control & 6.0 & 220 & 52000 & 1.25 & 162 & 65 \\
\hline A1 & 3.90 & 320 & 25200 & 1.161 & 135.98 & 69 \\
\hline A2 & 2.87 & 420 & 24560 & 1.142 & 129.45 & 68 \\
\hline
\end{tabular}




\begin{tabular}{|c|c|c|c|c|c|c|}
\hline A3 & 4.23 & 375 & 27459 & 1.171 & 142.62 & 68 \\
\hline A4 & 4.05 & 175.60 & 20520 & 1.102 & 162.97 & 75 \\
\hline A5 & 3.80 & 186.60 & 26541 & 1.174 & 285.25 & 70 \\
\hline A6 & 4.05 & 198.60 & 24520 & 1.169 & 305.25 & 71 \\
\hline A7 & 4.50 & 185.60 & 28200 & 1.184 & 335.25 & 70 \\
\hline
\end{tabular}

\begin{tabular}{|l|l|l|l|l|l|l|}
\hline B2 & 4.55 & 190.25 & 29525 & 1.1187 & 332.4 & 69 \\
\hline B3 & 4.62 & 205.12 & 30250 & 1.1443 & 321.42 & 68 \\
\hline B4 & 4.05 & 200.50 & 30520 & 1.1058 & 292.50 & 64 \\
& & & & & & \\
\hline
\end{tabular}

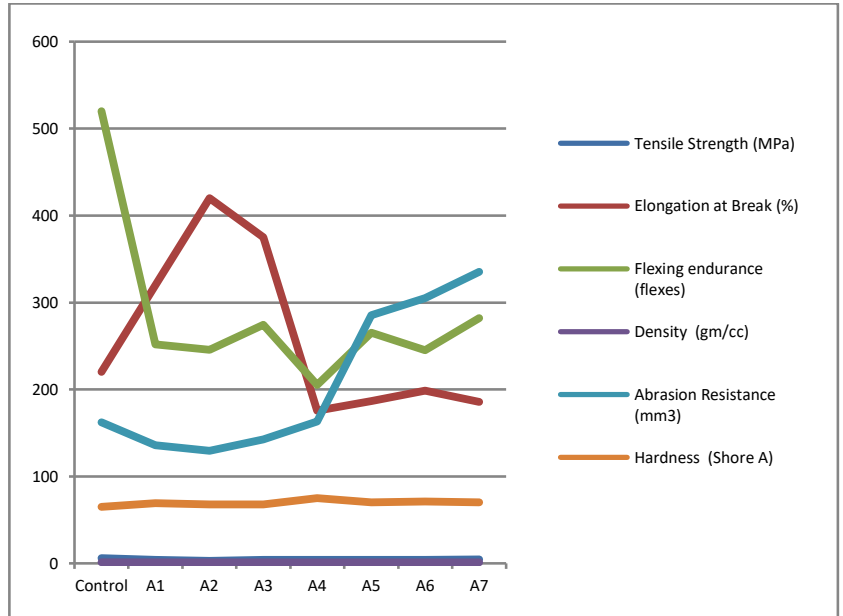

Figure 4: Line diagram of experiment I

The physical properties of soling materials were (by different elastomer and chrome waste) tabulated in table 6 .In this experiment eight different trails were conducted namely A1, A2, A3, A4, A5, A6 and A7.When we adding the EPDM rubber in the mixes the abrasion resistance values are enormously increased than the control sample. However, the tensile strength value and sole flexing values are slightly lesser than the control sample. Based on physical properties value obtained for the various trails A1, A2, A3, A4, A5, A6 and A7, it is concluded that the composition of trail A7 consider for further study.

Table 9: Physical properties of soling materials prepared using chrome shaving waste and different proposition of Isoprene and EPDM Rubber.

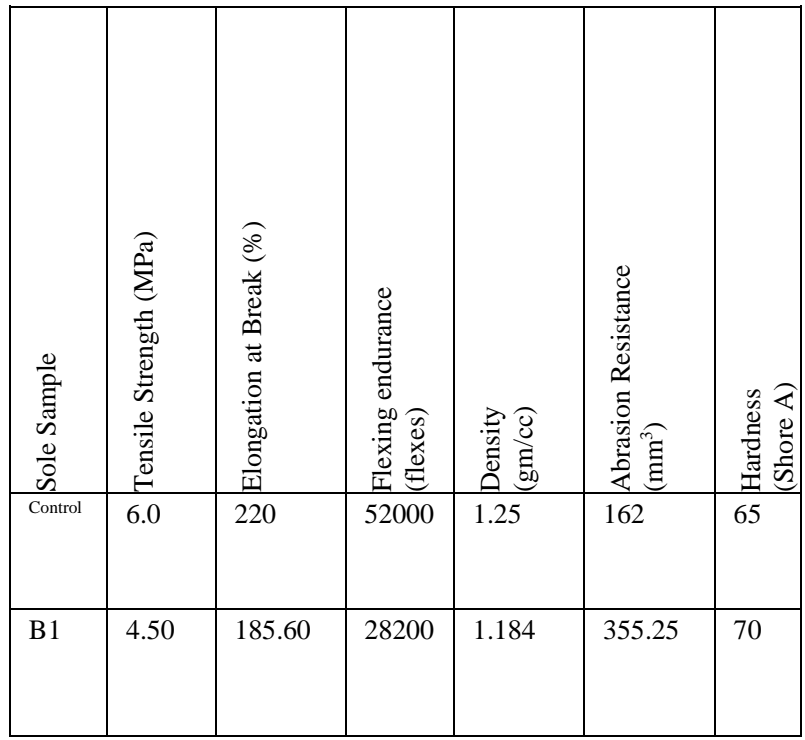

Retrieval Number: A1818109119/2019@BEIESP

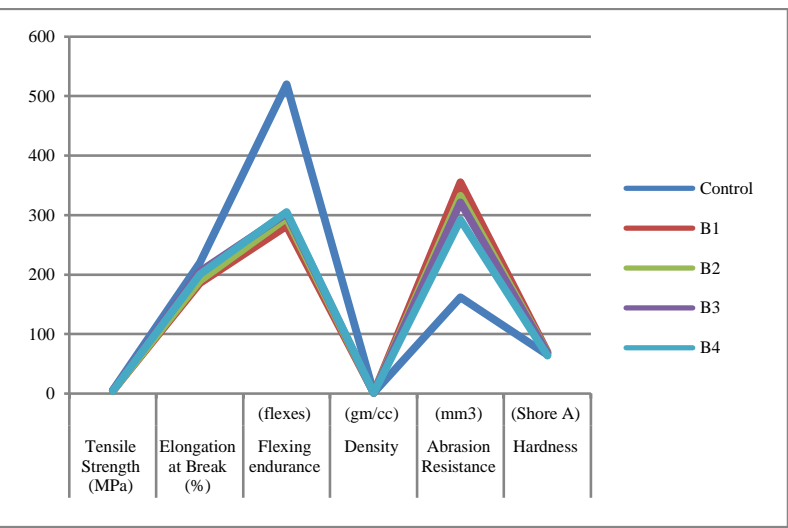

Figure 5: Line diagram of experiment II

The physical testing values of soling materials prepared using chrome shaving waste and different proposition of Isoprene and EPDM Rubber are tabulated in table 7.It is very clear that the marginal increase in tensile and sole flexing while increasing the quantity of Isoprene rubber in the chemical composition. Based on the physical testing value of the sole samples B1, B2, B3 and B4, the trail B2 (Isoprene-70 Phr and EPDM $30 \mathrm{Phr}$ ) is very near to the control value. it is concluded that the composition of trail B2 is consider for further study.

Table 10: Physical properties of soling materials prepared using chrome shaving waste and Isoprene and EPDM Rubber with different types of nano fillers.

\begin{tabular}{|c|c|c|c|c|c|c|}
\hline 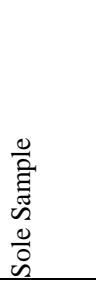 & 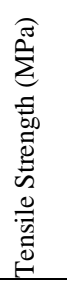 & 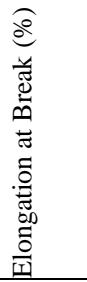 & 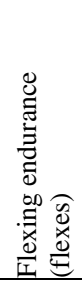 & 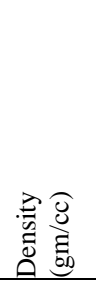 & 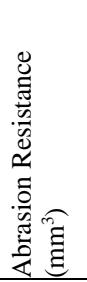 & 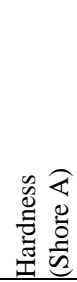 \\
\hline Control & 6.0 & 220 & 52000 & 1.25 & 162 & 65 \\
\hline C1 & 5.05 & 185.50 & 38520 & 1.1058 & 292.50 & 64 \\
\hline C2 & 5.8 & 189.20 & 40500 & 0.979 & 284.20 & 69 \\
\hline C3 & 5.5 & 190.40 & 39635 & 0.984 & 285.89 & 71 \\
\hline
\end{tabular}


Characterisation of Shoe Soling Material Prepared by using Rubber and Leather Solid Waste

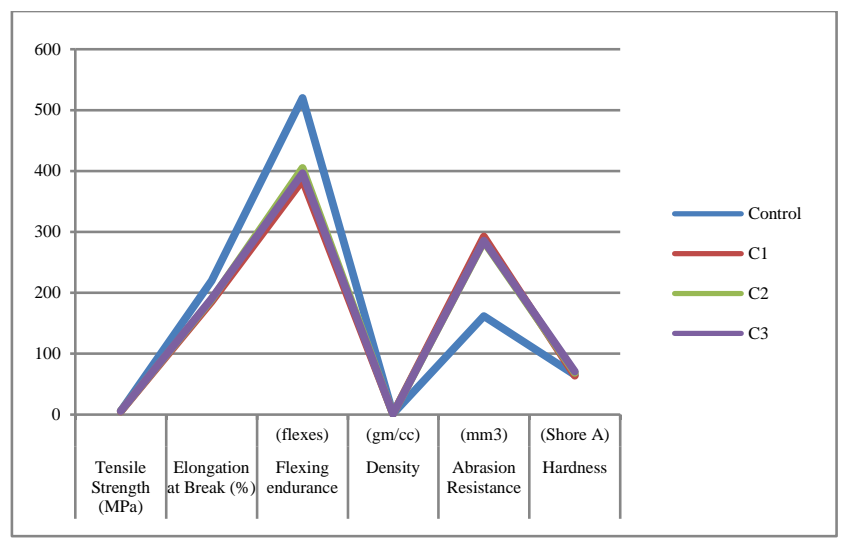

Figure 6: Line diagram of experiment III

The physical testing values of soling materials prepared using chrome shaving waste and Isoprene and EPDM Rubber with different types of nano fillers (SI,KLN \&BNT) tabulated in table 8 .It is clear that the marginal decrease of density of soling material due to the replacement of $\mathrm{CaCO}_{3}$ nano fillers. All the trails with nano fillers showed similar or higher tensile strength than the control soling material. Among the three inorganic nano fillers, KLN nano filler and SI nano filler exhibits good physical properties when compare to control soling materials. The physical properties show the good mutual compactability between rubbers and chrome shaving. Hence, the trail C2 (KLN nano filler) can be consider for further development of soling material.

Table: 11 Physical properties of soling materials prepared using chrome shaving waste and Isoprene and EPDM Rubber with different quantity of KLN nano fillers.

\begin{tabular}{|c|c|c|c|c|c|c|}
\hline 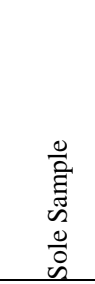 & 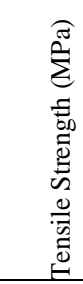 & 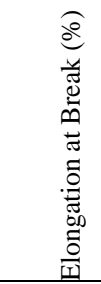 & 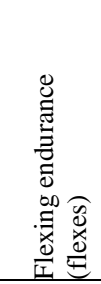 & 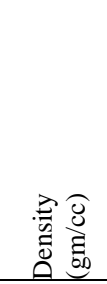 & 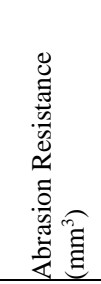 & 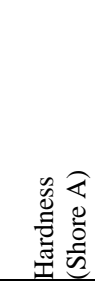 \\
\hline Control & 6.0 & 220 & 52000 & 1.25 & 162 & 65 \\
\hline D1 & 5.4 & 178.20 & 38500 & 0.998 & 281.14 & 69 \\
\hline D2 & 5.6 & 185.28 & 39800 & 0.989 & 282.35 & 69 \\
\hline D3 & 5.8 & 189.20 & 40500 & 0.979 & 284.20 & 69 \\
\hline D4 & 5.9 & 190.52 & 42360 & 0.972 & 284.41 & 69 \\
\hline D5 & 5.9 & 192.34 & 43200 & 0.975 & 286.45 & 69 \\
\hline D6 & 5.9 & 198.56 & 43383 & 0.975 & 285.63 & 69 \\
\hline
\end{tabular}

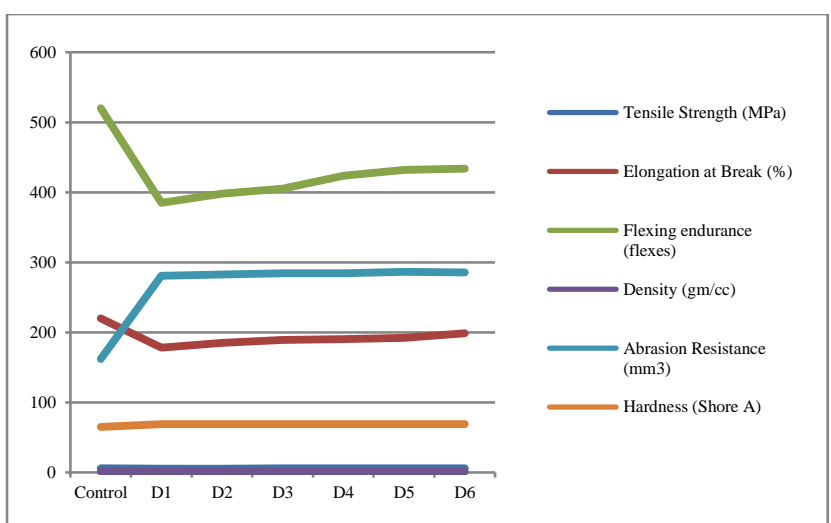

Figure 7: Line diagram of experiment IV

Physical properties of soling materials prepared using chrome shaving waste and Isoprene and EPDM Rubber with different quantity of KLN nano fillers are tabulated in table 9 .It is clear that the sole samples with 7-11 Phr of nanoparticle (D4, D5 and D6) showed higher physical properties than that of the control sole. Due to cost constrain the soling material made up of $7 \mathrm{Phr}$ of KLN nano filler can be consider for further development.

\section{CONCLUSION}

Footwear components were effectively prepared by the rubbers, chrome shaving and inorganic nano fillers. The Scanning Electron Microscopy images showed that the chrome shavings are good compatibility with EPDM rubber and isoprene rubber. The soling material with commercial filler $\mathrm{CaCO}_{3}$ shows good physical properties except the sole flexing and tensile strength. The replacement of KLN nano fillers by $\mathrm{CaCO}_{3}$ in this study improved the tensile strength and sole flexing properties of the soling material. Therefore, the isoprene-70 Phr, EPDM-30 Phr, Chrome shaving -50 $\mathrm{Phr}$ and inorganic nanoparticles-7 $\mathrm{Phr}$ sample can considered for further development and this will be the effective way to utilize solid waste generated by the leather industries and avoid the environmental issues.

\section{REFERENCES}

1. Report of the meeting of the IULTCS Tannery wastes commission (1981).Waalwijk, Holland 9-11 May.

2. Srinivasan $T$ S., M Anendrakumal: Krishnan $T$ S and $K . J$ Scaria(1985)"Chrome Shavings-a tannery waste, current practice and future trends for its utilization "Presented in the $3^{\text {rd }}$ AAP Animal Science Congress,Seoul,Korea.

3. Okamura H \&Shirai K, Chrome shavings and its products, J Am Leather ChemAssoc, 71 (1976) 173-179.

4. Cot J \&Gratacos E, Chrome shavings treatments, AQEIC Bol.Tech, 26 (1975) 353-376.

5. Suseela K, Parvathi M S \&Nandy S C, Chromium containing leather wastes, Leder, 34 (1983) 82-87.

6. DhanasekaranPrakash and Sellamuthu N. Jaisankar*, Thermoplastic poly(urethane-thiourethane) triblock copolymers with SWCNTs composite,Diam. Relat. Mater.93, 34-41, 2019.

7. Sellamuthu N. Jaisankar, Donna J. Nelson and Christopher Brammer, Preparation and properties of thermoplastic nanocomposites based on polyurethane ionomers, Proc. of 53rd Pentasectional Meeting of the American Chemical Society, 14, 2008. 
8. Seena Joseph, Tushar S. Ambone, Abhijit V. Salvekar, S. N. Jaisankar, P. Saravanan E. Deenadayalan, Processing and characterization of waste leather based polycaprolactonebiocomposites, Polym. Composite (DOI: 10.1002/pc.23891) (In Press 2015).

9. Rajeswari,N. Malarvizhi, E. Deenadayalan and Sellamuthu N Jaisankar* Influences of functionalized nanoclays on morphology and mechanical properties of polyvinyl alcohol based composites by twin-screw extruder, Polym. Plast. Technol. Eng.56, 883-888, 2017

10. Anoop V, SubramaniSankaraiah, S. N. Jaisankar, SohiniChakraborty\& Mary N.L, Enhanced mechanical, thermal and adhesion properties of polysilsesquioxane spheres reinforced epoxy nanocomposite adhesive, J. Adhes., 2019, DOI: $10.1080 / 00218464.2019 .162010$

\begin{tabular}{|c|c|l|l|l|}
\hline 7 & 1986 & 1987 & $\begin{array}{l}\text { Harcourt Butler } \\
\text { Technological } \\
\text { Institute, } \\
\text { (H.B.T.I.) Kanpur, } \\
\text { Uttar Pradesh }\end{array}$ & $\begin{array}{l}\text { Senior } \\
\text { Researc } \\
\text { h } \\
\text { Fellow }\end{array}$ \\
\hline 8 & 1985 & 1986 & $\begin{array}{l}\text { J. K. Synthetics, Kota, } \\
\text { Rajasthan }\end{array}$ & $\begin{array}{l}\text { Chemic } \\
\text { al } \\
\text { Enginee } \\
\text { r }\end{array}$ \\
\hline
\end{tabular}

\section{AUTHORS PROFILE}

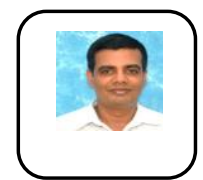

S.Ponsubbiah,ponsubbiah@gmail.com

Working as a lecturer in Institute of Leather Technology, Tharamani, Chennai-113.I am the bachelor in Leather Technology and masters in Footwear technology. I have completed my B.Tech and M.Tech in Anna University, Chennai.I have more than 12 years of Teaching experience in the same institution and four years industrial experience. At present I am doing my Ph.D under the supervision of Dr.Sanjeev Gupta in CSIR-CLRI,Adyar,Chennai-20.I have published six research papers relevant to this research.

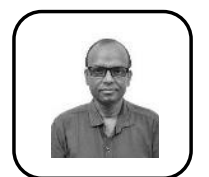

Dr.Sanjeev Gupta, Chief Scientist,CSIRCLRI,Adyar,Chennai-20. sgupta1281@gmail.com

$\mathrm{He}$ is the eminent scientist in the area of Leather technology and he has published more than 80-research paper.The educational and the research experiences are

listed below

Academic /Research Experience/Employment :

\begin{tabular}{|c|c|c|c|c|}
\hline Sl.No & From & To & Name & $\begin{array}{l}\text { Positio } \\
\text { n Held }\end{array}$ \\
\hline 1 & $\begin{array}{c}01.01 .201 \\
2\end{array}$ & Till date & $\begin{array}{l}\text { CSIR-Central Leather } \\
\text { Research Institute, } \\
\text { Chennai, Tamil Nadu }\end{array}$ & $\begin{array}{l}\text { Chief } \\
\text { Scientis } \\
\mathrm{t}\end{array}$ \\
\hline 2 & $\begin{array}{c}01.01 .200 \\
6\end{array}$ & 31.12.2012 & $\begin{array}{l}\text { CSIR-Central Leather } \\
\text { Research Institute, } \\
\text { Chennai, Tamil Nadu }\end{array}$ & $\begin{array}{l}\text { Senior } \\
\text { Principa } \\
\mathrm{l} \\
\text { Scientis } \\
\mathrm{t} \\
\text { Gr. } \\
\text { IV(5) }\end{array}$ \\
\hline 3 & $\begin{array}{c}01.01 .200 \\
1\end{array}$ & 31.12.2005 & $\begin{array}{l}\text { CSIR-Central Leather } \\
\text { Research Institute, } \\
\text { Chennai, Tamil Nadu }\end{array}$ & $\begin{array}{l}\text { Principa } \\
\mathrm{l} \\
\text { Scientis } \\
\mathrm{t} \\
\text { Gr. } \\
\text { IV(4) }\end{array}$ \\
\hline 4 & $\begin{array}{c}05.08 .199 \\
6\end{array}$ & 31.12 .2000 & $\begin{array}{l}\text { CSIR-Central Leather } \\
\text { Research Institute, } \\
\text { Chennai, Tamil Nadu }\end{array}$ & $\begin{array}{l}\text { Senior } \\
\text { Scientis } \\
\mathrm{t} \\
\text { Gr. } \\
\text { IV(3) }\end{array}$ \\
\hline 5 & $\begin{array}{c}05.08 .199 \\
1\end{array}$ & 04.08.1996 & $\begin{array}{l}\text { CSIR-Central Leather } \\
\text { Research Institute, } \\
\text { Chennai, Tamil Nadu }\end{array}$ & $\begin{array}{l}\text { Scientis } \\
\mathrm{t} \\
\text { Gr. } \\
\text { IV(2) }\end{array}$ \\
\hline 6 & 1987 & 1991 & $\begin{array}{l}\text { Harcourt Butler } \\
\text { Technological } \\
\text { Institute, } \\
\text { (H.B.T.I.) Kanpur, } \\
\text { Uttar Pradesh }\end{array}$ & $\begin{array}{l}\text { Lecture } \\
\text { r }\end{array}$ \\
\hline
\end{tabular}

